\title{
Environmental Contamination of Flue-Cured Tobacco with Chlorinated Hydrocarbon Insecticides*
}

\author{
by J. J. Domanski and T. J. Sheets \\ Pesticide Residue Researh Laboratory, Raleigh, North Carolina, U.S.A.
}

\section{INTRODUCTION}

Residues of DDT and other chlorinated hydrocarbon pesticides in tobacco have declined in recent years, but DDT and TDE levels for the 1972 auction market survey exceeded tolerances assigned to food in the Federal Republic of Germany by several fold (x). Less than $1 \%$ of the samples contained residues which met the food tolerance of o.I ppm for DDT plus TDE, but over $90 \%$ of the samples contained residues between 0.1 and $0.5 \mathrm{ppm}$. We speculated that most of these residues may have come from residues in soil and air and not from direct application (2) of the insecticide. Sheets et al. (10) and Reed and Priester (6) reported contamination by DDT and dieldrin of tobacco grown in soils which had been treated with these insecticides prior to transplanting the tobacco. A recent report by Rosa and Cheng (7) confirmed uptake and translocation of DDT by tobacco grown in nutrient solution, quartz sand, and soil.

We initiated this study to determine if flue-cured tobacco grown under currently recommended cultural practices could become contaminated with levels of DDT, TDE, endrin, dieldrin, and toxaphene that exceed tolerances assigned to food and proposed for tobacco.

\section{EXPERIMENTAL METHODS}

Plots were located on the Border Belt Tobacco Research Station (Whiteville, North Carolina), the Central Crops Research Station (Clayton, North Carolina), the Upper Coastal Plain Research Station (Rocky Mount, North Carolina), and the Oxford Tobacco Research Station (Oxford, North Carolina). Tobacco (Nicotiana tabacum L.) was grown during the 1973 season in two-row plots (40 plants/row) $20 \mathrm{~m}$ long with rows $1.06 \mathrm{~m}$ apart. The cultural practices suggested by the North Carolina Agricultural Experiment Station were employed from the time of seed bed preparation to the time of harvest. The history of use of DDT, TDE, endrin, dieldrin, and toxaphene on the fields in this study varied from those with no record of use of a specific pesticide to those

\footnotetext{
- Paper No. 4764 of the Jouraal Series of the North Carolina Agricultural Experiment Station, Raleigh, Norsh Carolina.

Received for publication: 2tat October, 1975.
}

with frequent use; but DDT, TDE, endrin, or dieldrin had not been used on any plot area within the past 4 years. Toxaphene had never been used on the Border Belt and Oxford Research Stations except in small experimental plots, but it had been used each year in some fields at the Central Crops and Upper Coastal Plain Stations. At all locations, except at the Central Crops Research Station where bulk-curing was employed, the tobacco was harvested and cured in conventional barns. Tobacco leaf samples were taken from the bottom third, middle third, and top third stalk positions.

Soils were sampled at random, in the row, between plants to a depth of $15 \mathrm{~cm}$ shortly after transplanting. Additional soil samples were taken in November, 1973, at the Border Belt location in $15 \mathrm{~cm}$. increments to a depth of $75 \mathrm{~cm}$.

At the time of transplanting in the spring of 1974 , tobacco plants and plant-bed soil in which they were grown were sampled at all locations. The soil was sampled to a depth of $15 \mathrm{~cm}$.

Tobacco was extracted and analyzed by the method previously reported (3). Forty grams of soil were extracted in a Soxhlet extractor with $\mathrm{CHCl}_{9}: \mathrm{MeOH}$ (9:1, v/v) as a solvent with six solvent turnovers pex hour. The extract was filtered through anhydrous $\mathrm{Na}_{2} \mathrm{SO}_{4}$ and then concentrated to about $1 \mathrm{ml}$. The extract was made up to approximately $5 \mathrm{ml}$ with n-hexane and dromatographed on a Florisil column (3).

Samples were analyzed for DDT, TDE, endrin, dieldrin, and toxaphene. The presence of DDT and TDE was confirmed according to the method of Miles (5).

Moisture percents of the soil and tobacco were determined and insecticide residues reported on a dry weight basis for soil and a $13 \%$ moisture basis for the tobacco.

\section{RESULTS AND DISCUSSION}

All tobacco and most soil samples contained measurable residues of DDT and TDE (Table 1 ). The lowest residues of DDT plus TDE in soil and cured tobacco were from the Oxford Station. Soils from the Upper Coastal Plain Station had the greatest levels of these pesticides but levels found in the cured leaf from the Upper Coastal Plain Station were second highest after those in the leaf from Central Crops Station. 
Levels of DDT and TDE for individual samples ranged from $<0.01$ to $0.18 \mathrm{ppm}$ for the soil and from 0.11 to $1.69 \mathrm{ppm}$ for the tobacco. Values for individual samples are not reported. The lowest stalk leaves generally had a higher concentration of DDT + TDE than the middle and upper leaves for the Border Belt Research Station and the Upper Coastal Plain Station. This result is in agreement with that of Rosa and Cheng (8) who reported the greatest concentration of DDT in bottom leaves. Distribution of DDT and TDE residues among leaf positions was variable for other locations, and several samples from middle and upper stalk positions contained DDT and TDE residues that were equal to or greater than those for the low position. Only residues of DDT in the bottom stalk position were correlated linearly (significant at $5 \%$ level) with those in the soil. One possible explanation why only bottom leaves were correlated with the residues found in the soil is that dust containing DDT might drift from other areas to contaminate the upper portion of the plant more than the lower leaves (i.e., the upper leaves might shield the lower leaves from fallout) and mask the relation between residues in upper leaves and those in soil.

The presence of DDT and its analogues were confirmed in the tobacco by converting them to $3,4^{-}$and $4,4^{\prime}-$ dichlorobenzophenones. In general, the values obtained for the dichlorobenzophenones were in good agreement with those of DDT and TDE. In addition, the residue levels of DDT-TDE found in this experiment were similar to those reported for tobacco from the 1972 auction market (2). Therefore, as previously speculated, most of the DDT-TDE residues found on the 1972 tobacco offered for sale by farmers probably were a result of contamination, especially from the soil in which the tobacco was grown.

Analyses of soil samples taken in November of 1973 from three of the experimental fields to depths of $75 \mathrm{~cm}$ showed that the greatest concentration of DDT was in the upper $15 \mathrm{~cm}$ and none was detected between 30 and $75 \mathrm{~cm}$ below the surface. Hence, we concluded that the surface soil was a greater potential source of DDT residue than soil below $30 \mathrm{~cm}$. If one assumes that the insecticide was uniformly distributed in the upper $30 \mathrm{~cm}$ of soil, then a cylinder of soil with a diameter of $30 \mathrm{~cm}$, a depth of $30 \mathrm{~cm}$ and a density of $2.6 \mathrm{~g} / \mathrm{cm}^{3}$ would contain approximately $2200 \mu \mathrm{g}$ of DDT plus TDE based on the average concentration of these insecticides in the soil at the Border Belt Station (Table 1). The above-described cylinder is similar in volume to the 30.5 by 30.5 by $20 \mathrm{~cm}$ rectangular solid of soil which was permeated by the root system of a tobacco plant within 4.5 weeks after transplanting (4). A vigorous tobacco plant could produce about $225 \mathrm{~g}$ of cured tobacco. At the Border Belt Station the average residue in the cured leaves over all stalk positions was approximately $0.4 \mathrm{ppm}$ or $90 \mu \mathrm{g}$. This is only about 4 percent of the total residue $(2200 \mu \mathrm{g})$ found in the soil cylinder. Hence, there was sufficient insecticide available to the plant so that uptake by the roots could be a major source of the residue found in the leaves.

The greatest concentration of DDT, from uptake by

Table 1. Mean values for residues of DDT, TDE, toxaphene, endrin, and dleldrin In soll and tobacco by location.

\begin{tabular}{|c|c|c|c|c|c|c|c|c|c|}
\hline Research station & $\begin{array}{l}\text { Number } \\
\text { of fields } \\
\text { sampled }\end{array}$ & $\begin{array}{l}\text { Tobacco } \\
\text { or soll }\end{array}$ & $\begin{array}{c}\text { Stalk } \\
\text { position }\end{array}$ & {$\left[\begin{array}{c}\text { Total DDT } \\
(\mathrm{ppm})\end{array} \mid\right.$} & $\begin{array}{c}\text { Total TDE } \\
(\mathrm{ppm})\end{array}$ & $\underset{\text { TDE }}{\text { DDT }+}$ & $\begin{array}{l}\text { Toxa- } \\
\text { phene } \\
\text { (ppm) }\end{array}$ & $\begin{array}{l}\text { Endrin } \\
(\mathrm{ppm})\end{array}$ & $\begin{array}{c}\text { Dieldrin } \\
\text { (ppm) }\end{array}$ \\
\hline \multirow[t]{4}{*}{ Border Belt Tobacco } & 12 & Soil & & 0.07 & 0.01 & 0.08 & $<0.10$ & $<0.01$ & 0.01 \\
\hline & & Tobacco & Bottom & 0.41 & 0.15 & 0.56 & $<0.30$ & 0.01 & $<0.01$ \\
\hline & & Tobacco & Middle & 0.26 & 0.09 & 0.35 & 0.57 & $<0.01$ & $<0.01$ \\
\hline & & Tobacco & Top & 0.21 & 0.08 & 0.29 & 0.40 & $<0.01$ & $<0.01$ \\
\hline \multirow[t]{4}{*}{ Central Crops } & 3 & Soil & & 0.05 & 0.02 & 0.07 & 2.19 & 0.01 & $<0.01$ \\
\hline & & Tobacco & Bottom & 0.28 & 0.36 & 0.64 & 1.44 & 0.01 & $<0.01$ \\
\hline & & Tobacco & Mjddle & 0.11 & 0.54 & 0.65 & 1.24 & $<0.01$ & $<0.01$ \\
\hline & & Tobacco & Top & 0.08 & 1.08 & 1.16 & 1.29 & 0.01 & $<0.01$ \\
\hline \multirow[t]{4}{*}{ Upper Coastal Plain } & 5 & Soil & & 0.09 & 0.03 & 0.12 & 1.61 & 0.04 & 0.01 \\
\hline & & Tobacco & Bottom & 0.92 & 0.06 & 0.98 & 1.86 & 0.02 & 0.01 \\
\hline & & Tobacco & Middle & 0.37 & 0.07 & 0.44 & 3.63 & 0.01 & 0.02 \\
\hline & & Tobacco & Top & 0.31 & 0.08 & 0.39 & 2.39 & $<0.01$ & $<0.01$ \\
\hline \multirow[t]{4}{*}{ Oxford Tobacco } & 2 & Soil & & 0.01 & $<0.01$ & 0.01 & $<0.10$ & $<0.01$ & $<0.01$ \\
\hline & & Tobacco & Bottom & 0.09 & 0.04 & 0.13 & $<0.30$ & $<0.01$ & $<0.01$ \\
\hline & & Tobacco & Middle & 0.08 & 0.05 & 0.13 & $<0.30$ & 0.01 & $<0.01$ \\
\hline & & Tobacco & Top & 0.06 & 0.05 & 0.11 & $<0.30$ & 0.02 & $<0.01$ \\
\hline \multirow[t]{4}{*}{ All Stations } & 22 & Soil & & 0.07 & 0.01 & 0.08 & 0.68 & 0.02 & $<0.01$ \\
\hline & & Tobacco & Bottom & 0.48 & 0.15 & 0.63 & 0.66 & 0.01 & $<0.01$ \\
\hline & & Tobacco & Middle & 0.25 & 0.14 & 0.39 & 0.13 & $<0.01$ & $<0.01$ \\
\hline & & Tobacco & Top & 0.20 & 0.22 & 0.42 & 0.96 & $<0.01$ & $<0.01$ \\
\hline
\end{tabular}


Table 2. Resldues of DDT in tobacco and soll from plant bede from the 1974 crop.

\begin{tabular}{|c|c|c|c|}
\hline Research station & $\begin{array}{l}\text { Soll or } \\
\text { tobacco }\end{array}$ & Variety & $\begin{array}{l}\text { Total DDT } \\
\text { (ppm) }\end{array}$ \\
\hline $\begin{array}{l}\text { Border Belt } \\
\text { Tobacco }\end{array}$ & $\begin{array}{l}\text { Soll } \\
\text { Tobacco }\end{array}$ & NC-2326 & $\begin{array}{l}5.59 \\
0.34\end{array}$ \\
\hline Central Crops & $\begin{array}{l}\text { Soll } \\
\text { Tobacco }\end{array}$ & NC-2326 & $\begin{array}{l}0.50 \\
0.05\end{array}$ \\
\hline $\begin{array}{l}\text { Upper Coastal } \\
\text { Plain }\end{array}$ & $\begin{array}{l}\text { Soil } \\
\text { Tobacco }\end{array}$ & NC-2326 & $\begin{array}{l}0.01 \\
0.05\end{array}$ \\
\hline Oxford Tobacco & $\begin{array}{l}\text { Soll } \\
\text { Tobacco }\end{array}$ & G-28 & $\begin{array}{l}1.28 \\
0.22\end{array}$ \\
\hline
\end{tabular}

tobacco from soil treated with this insecticide, was found in the roots and only about to percent or less was present in the leaves $(8,9)$. Plowing under of roots and stalks after harvest of tobacco leaves is a recommended practice. Although the residue levels in the field could be lowered by removal of all plant parts after harvest, it would not be practical to remove the root system. Rosa and Cheng (9) suggested that cyclins of DDT between soil and the root would tend to prolong its persistence. Therefore, DDT and TDE residues may persist at low levels for some time but will also decrease as the levels in the soil decrease.

Since tobacco plant beds were heavily treated with DDT in the past, they were sampled in 1974 to determine if contamination of plants could occur before transplanting. Residues in plant-bed leaves appeared to be related to levels in plant-bed soils (Table 2); however, the low residue of DDT found in the young plants from the beds would be diluted by subsequent growth of the tobacco, and plant-bed leaves usually are not harvested in normal operations. Therefore, DDT from the plant bed appears to cause insignificant contamination at the time of harvest.

Residues of endrin and dieldrin were low in both the soil and cured leaf. The levels found in this experiment were similar to those reported for tobacco sampled at time of sale $(2,3)$.

Residues of toxaphene for individual samples ranged from $<0.1$ to 4.7 in soil and $<0.3$ to 7.7 on cured tobacco. The highest average residues as well as individual values on tobacco were found at the Central Crops and Upper Coastal Plain Research Stations (Table 1). At both of these locations, toxaphene was applied to cotton growing nearby during the harvest season for tobacco. One field at the Central Crops Research Station had no record of toxaphene use. The soil from this field contained $<0.1$ ppm (low detectable limit); yet concentrations in cured leaf from this plot ranged between 0.95 and $1.39 \mathrm{ppm}$. The closest known applications of toxaphene during the time the tobacco was in the field was $>1.00 \mathrm{~m}$. We assumed that drift was a major cause of contamination of middle and upper leaves by toxaphene. Residues in the soil were correlated with levels found in the tobacco sampled from the bottom and top stalk positions (significant at $I \%$ level). Thus, residues of toxaphene in the soil of these fields may also be a source of contamination.

Concentrations of toxaphene in the cured leaf, like the residues of the other chlorinated pesticides reported here, were similar to those reported for the 1972 auction market tobacco.

\section{CONCLUSIONS}

Although these experiments were not designed to differentiate between possible sources of contamination of tobacco by chlorinated insecticides, they clearly show that tobacco grown under recommended cultural practices and specifically with no direct application of chlorinated pesticides may not generally meet tolerances proposed for one or more of the restricted insecticides. The residue levels for all insecticides studied here were similar to those reported for our 1972 survey of U.S. auction market tobacco. Therefore, most of the residue found on the 1972 crop could have been a result of indirect contamination from environmental sources, and further reductions in leaf residues of DDT, TDE, endrin and dieldrin may be gradual. Low residues of toxaphene may continue to be found if tobacco is grown on soils containing toxaphene residues or if it is grown in close proximity to other crops that are sprayed with this insecticide. Imposition and enforcement of extremely low tolerances proposed by governments of some European countries would exclude U.S. tobacco from sale to these markets. Modification of the tolerances to permit low levels of pesticide residues resulting from environmental contamination seems a justifiable alternative. Nevertheless, research and educational efforts to minimize residues on tobacco should remain as a major goal.

\section{SUMMARY}

Indirect contamination of tobacco by DDT, TDE, endrin, dieldrin, and toxaphene was investigated under field conditions. Levels of DDT + TDE in soil ranged from $<0.01$ to $0.18 \mathrm{ppm}$, and those in cured leaves ranged from 0.11 to $1.69 \mathrm{ppm}$. The lower stalk position at the major test location generally had greater concentrations of DDT + TDE than the middle and upper positions, but distribution of these insecticides among leaf positions was variable for other locations. Residues of DDT in the bottom stalk position were positively correlated with those in the soil. Plant-bed soils did not appear to be a major source of DDT + TDE residues in cured tobacco. Residues of endrin and dieldrin were near or below the limit of detection ( $0.01 \mathrm{ppm})$ in soil and cured leaf. Residues of toxaphene ranged from $<0.1$ to $4.7 \mathrm{ppm}$ in soil and $<0.3$ to $7.7 \mathrm{ppm}$ on tobacco. Toxaphene residues in the bottom 
and top stalk positions were positively correlated with residues in soil. Contamination by toxaphene appeared to be attributable to uptake from soil and to movement of the insecticide as drift or vapor through the air.

\section{ZUSAMMENFASSUNG}

Es wird über die Untersuchung der indirekten Verunreinigung des Tabaks mit DDT, TDE, Endrin, Dieldrin und Toxaphen in Feldversuch berichtet. Der Boden enthielt zwischen $<_{0,01}$ und $0,18 \mathrm{ppm}$ DDT + TDE, und der Gehalt der getrockneten Blätter lag zwischen 0,11 und 1,69 ppm. In den hauptsächlichen Versuchsfeldem zeigten sich im allgemeinen bei niedrigerer Blattposition höhere Konzentrationen an DDT + TDE als bei mittlerer oder höherer Blattposition; in anderen Feldern wurde aber in bezug auf die Blattposition eine unterschiedliche Verteilung dieser Insektizide beobachtet. Es zeigte sich eine positive Korrelation zwischen den Rückständen an DDT in der unteren Blattposition und denen im Boden. Der Boden der Anzuchtbeete schien nicht die Hauptursache für die Rückstände an DDT + TDE im getrockneten Tabak zu sein. Die Rückstände an Endrin und Dieldrin im Boden und im getrockneten Blatt befanden sich nahe oder unterhalb der Nachweisgrenze (o,or ppm). Die Toxaphenrückstände lagen im Boden bei $<_{0,1}$ bis 4,7 ppm und in Tabak bei $<0,3$ bis 7,7 ppm. Es bestand eine positive Korrelation zwischen den Toxaphenrüdkständen in der unteren und oberen Blattposition und denen im Boden. Die Verunreinigung mit Toxaphen schien auf die Aufnahme aus dem Boden und auf Transport des Insektizids durch die Luft in festem oder dampfförmigem Zustand zurückzuführen zu sein.

\section{RESUME}

On a étudié sur le terrain la contamination indirecte du tabac par le DDT, TDE, l'endrin, le dieldrin et le toxaphène. La concentration du DDT + TDE du sol se situe entre $<_{0,01}$ et $0,18 \mathrm{ppm}$, et celle des feuilles séchées entre 0,11 et 1,69 ppm. A l'endroit où on a effectué les tests principaux la concentration du DDT + TDE est généralement plus élevée dans les branches basses que dans les branches à mi-hauteur ou supérieurés. Cependant à d'autres endroits, la distribution de ces insecticides ne correspond pas à une hauteur donnée de la feuille, mais est variable. Les résidus de DDT dans les branches de base sont en corrélation directe avec les résidus trouvés dans le sol. La terre des couches de culture ne semble pas représenter une source majeure de résidus de DDT + TDE dans le tabac séché. Les résidus d'endrin et de dieldrin restent proches ou en dessous de la limite de détection (0,01 ppm) dans le sol et dans les feutilles séchées. Les résidus de toxaphène représentent de $<_{0,1}$ à $4,7 \mathrm{ppm}$ dans le sol et de $<_{0,3}$ à $7,7 \mathrm{ppm}$ dans le tabac. Les résidus de toxaphène dans les branches de base et dans les branches supérieures sont en corrélation directe avec les résidus dans le sol.
Il semble que la contamination par le toxaphène s'effectue par l'assimilation en provenance du sol ainsi que par le mouvement de l'insecticide dans l'atmosphère sous forme de tourbillon ou de vapeur.

\section{REFERENCES}

1. Anonymous: Bundesgesetzblatt 1966, Teil 1, Nr. 53, $Z 1997$ A, Seite 667, ausgegeben zu Bonn am 10. Dezember 1966 / amended 14th December, 1972, and 5 th June, 1973.

2. Domanski, J. J., P. L. Haire, and T. J. Sheets: Insecticide residues on 1972 U.S. auction-market tobacco; Beitr. Tabakforsch. 8 (1975) 39.

3. Domanski, J. J., and T. J. Sheets: Insecticide residues on 1970 U.S. auction market tobacco; Tob. Sci. 17 (1973) 55 .

4. Hall, N. S., W. F. Chandler, C. H. M. van Bavel, P. H. Reid, and J. H. Anderson: A tracer technique to measure growth and activity of plant root systems; North Carolina Agr. Exp. Sta. Tech. Bull. No. 101, 40 pp., 1953.

5. Miles, J. R. W.: Conversion of DDT and its metabolites to dichlorobenzophenones for analysis in the presence of polychlorinated biphenyls; J. A. O. A. C. 55 (1972) 1039.

6. Reed, J. K., and L. E. Priester: DDT residues in tobacco and soybean grown in soil treated with DDT; Pestic. Monit. J. 3 (1.,969) 87.

7. Rosa, N., and H. H. Cheng: Uptake of DDT by Nicotiana tabacum; Can. J. Plant Sci. 53 (1973) 443.

8. Rosa, N., and H.H.Cheng: Distribution of DDT-14C in Nicotiana tabacum; Can. J. Plant Sci. 54 (1974) 403 .

9. Rosa, N., and $H$. $H$. Cheng: The effect of soil composition and length of exposure to DDT on uptake by tobacco; Tob. Sci. 19 (1975) 71.

1o. Sheets, T. J., M. D. Jackson, W. J. Mistric, and W. V. Campbell: Residues of DDT and dieldrin in peanuts and tobacco grown on contaminated soil; Pestic. Monit. J. 3 (1969) 80.

\section{Acknowledgment}

We appreciate the financial support of this researdh provided by the American Tobacco Co., Brown and Williamson Tobacco Corp., Liggett and Myers, Inc., P. Lorillard, Philip Morris, Inc., R. J. Reynolds Tobacco Co., and Tobacco Advisory Committee (United Kingdom).

\section{The authors' address:}

North Carolina State University, School of Agriculture and Life Sciences, Dept. of Entomology, Pesticide Residue Research Laboratory, Box 5215, ZIP 27607, Raleigh, North Carolina, U.S.A. 